\title{
Chemical Weed Control in Taniers ${ }^{1}$
}

\author{
Lii-Chyuan Liu and Edwin Acevedo-Borrero ${ }^{2}$
}

\begin{abstract}
Two herbicide experiments were conducted on a Coto clay at the Isabela Substation to screen several promising herbicides at two rates each for weed control in taniers. Taniers were found to be highly tolerant to Diphenamid. In the first experiment the highest tuber yield was obtained with the herbicide treatment consisting of Diphenamid as preemergent and Glyphosate as postemergent. Ametryn and Linuron at the two rates tested gave good preemergence weed control. Nitrofen at the lower rate was not very effective, but at the higher rate provided better weed control. Metribuzin and Fluometuron were effective but were phytotoxic at the higher rate of application. Cyanazine was ineffective at lower rate and effective at higher rate. Glyphosate applied alone, despite its being plagued by injury problem, appeared promising for postemergence weed control in tanier. DCPA, Oryzalin and Perfluidone were ineffective in this test. Handweeding treatments produced the highest tuber yield in the second experiment.
\end{abstract}

\section{INTRODUCTION}

Taniers (Xanthosoma sagittifolium L.) are one of the major starchy food crops of the tropics. In Puerto Rico, taniers are second only to yams in economic importance among the starchy food crops. In 1977-78, tanier growers contributed 4.8 million dollars to the agricultural economy of the Island (1). In the same year, a total of 6,667 metric tons of taniers, with a cash value of $\$ 281,428$, was imported into Puerto Rico from the Dominican Republic and other Caribbean countries. One of the major factors limiting tanier production has been the scarcity and high cost of labor needed to combat weeds. It is in this respect that chemical weed control has become important for enhancing tanier production.

The status of weed control in major tropical root and tuber crops was extensively reviewed by Moody et al. (4). Most of reported research has been confined to taro (Colocasia spp.), a closely related species. In Hawaii, Plucknett et al. (6) reported good weed control with little injury to crop through the use of Trifluralin, Prometryn and Ametryn. In the West Indies, Kasasian and Seeyave (2) indicated that Prometryn at the rate of $1.2 \mathrm{~kg} / \mathrm{ha}$ gave four to eight weeks preemergence weed contru 1 with little injury to the crop. Lucas et al. (3) found that a combination of Paraquat and Prometryn was the best herbicide treatment in Niue. Plucknett and de la Peña (7) and de la Peña (5) reported that Nitrofen provided excellent weed control in irrigated and lowland taro. To date, there is no published information on chemical weed control in taniers in

\footnotetext{
${ }^{1}$ Submitted to Editorial Board September 21, 1979.

${ }^{2}$ Plant Physiologist and Research Assistant, respectively, Agricultural Experiment Station, Mayagüez Campus, University of Puerto Rico, Río Piedras, P. R.
} 
Puerto Rico. Two herbicide experiments on taniers were conducted at the Isabela Substation during 1977 and 1978 in an attempt to screen promising herbicides. This paper presents results from these two herbicide experiments.

\section{MATERIALS AND METHODS}

\section{EXPERIMENT 1}

An experiment was established on a Coto clay $(\mathrm{pH}$ 6.1, organic matter $2.6 \%$ ), at the Isabela Substation. A randomized complete block design with four replications was used. The individual plots consisted of four 6.4 $\mathrm{m}$ long rows spaced at $0.9 \mathrm{~m}$ between rows. The planting distance within the row was $0.6 \mathrm{~m}$. Tanier cultivar Morada was planted December 12 , 1977, on individual plots. Ametryn ${ }^{3}$ at 3.36 and $6.72 \mathrm{~kg} / \mathrm{ha}$, Diphenamid at 11.20 and $22.40 \mathrm{~kg} / \mathrm{ha}$, Linuron at 3.36 and $6.72 \mathrm{~kg} / \mathrm{ha}$, Metribuzin at 2.24 and $4.48 \mathrm{~kg} / \mathrm{ha}$, Nitrofen at 6.72 and $13.44 \mathrm{~kg} / \mathrm{ha}$, and Perfluidone at 3.36 and $6.72 \mathrm{~kg} / \mathrm{ha}$ were applied preemergently. All herbicides were broadcast from a knapsack sprayer equipped with nozzle tip 8004 that delivered a spraying volume of 281 1/ha. Postemergence herbicide applications were made with some of the herbicides mentioned above at half the initial rates. The first herbicide application was made December 13, 1977. The second and third applications were made February 14, 1978, and July 28, 1978, respectively. All fertilization and pest control practices were carried out according to the commercial practices for the region. Since the effect of the herbicides disappeared during the latter part of the growing season, handweedings were needed to maintain adequate growth of taniers. Weed control ratings and crop phytotoxicity evaluations were made periodically. The tubers were harvested on December 5, 1978, from two inner rows of each experimental plot. Yield was converted into $\mathrm{kg} / \mathrm{ha}$ basis.

\section{EXPERIMENT 2}

The second herbicide experiment was established at the same substation to test a few other promising herbicides not included in the first experiment. The same size of plot and planting distance as in the first experiment were used in this experiment. The experimental design was again a randomized complete block design with four replications. Tanier cultivar Blanca was planted May 11, 1978, on the same Coto clay soil. DCPA at $11.2 \mathrm{~kg} / \mathrm{ha}$, Oryzalin at $1.12 \mathrm{~kg} / \mathrm{ha}$, Fluometuron at 4.48 and

${ }^{3}$ Trade names in this publication are used only to provide specific information. Mention of a trade name does not constitute a warranty of equipment or materials by the Agricultural Experiment Station of the University of Puerto Rico, nor is this mention a statement of preference over other equipment or materials. 
$8.96 \mathrm{~kg} / \mathrm{ha}$, Cyanazine at 4.48, 8.96 and $17.92 \mathrm{~kg} / \mathrm{ha}$, and Metribuzin at $1.12 \mathrm{~kg} / \mathrm{ha}$ were applied preemergently either alone or in combination. Postemergence application of some of the above-mentioned herbicides was made at half of the initial rates. Glyphosate was the only straight postemergence herbicide included in this experiment. The first herbicide application was made May 12, 1978. The second and third herbicide applications were made June 12, 1978, and July 11, 1978, respectively. Weed control rating and phytotoxicity evaluations were made periodically. The tubers were harvested May 22, 1978, from two inner rows of each experimental plot. Yield was converted into $\mathrm{kg} / \mathrm{ha}$ basis.

\section{RESULTS AND DISCUSSION}

\section{EXPERIMENT 1}

The predominant weed species present in the experimental plots are listed in their decreasing order of abundance; spurge (Euphorbia heterophylla L.), sicklepod (Cassia tora L.), morning glory (Ipomoea tiliaceae (Willd.) Choisy), hairy beggarstick (Bidens pilosa L.), crabgrass (Digitaria sanguinalis (L.) Scop.), Noodsorrel (Oxalis intermedia A. Rich.), Alexander grass (Brachiaria plataginea (Link) A. Hitch.), ragweed parthenium (Parthenium hysterophorum L.), Jamaica vervain (Stachyrtarpheta jamaicensis (L.) Vahl.), Bermuda grass (Cynodon dactylon (L.) Pers.), lion's ear (Leonotis nepetaefolia (L.) R. Br.), and purple nutsedge (Cyperus rotundus L.). Of the six preemergence herbicides tested, Metribuzin and Linuron at both rates provided good to excellent weed control (table 1). Diphenamid treatment gave excellent grass control but was weak on morning glory and spurge. Because Diphenamid lacks the postemergence herbicide activity, Glyphosate was supplemented later to give sustained weed control. Ametryn at both rates provided good initial broadleaf weed control but did not give adequate control of Alexander grass as a result of shift of weed population to grass species. The weed control was not very good at the lower rate of Nitrofen; however, it improved somewhat at higher rate of Nitrofen. Plucknett et al. (7) and de la Peña (5) reported that in Hawaian taro plantations excellent weed control was obtained with Nitrofen. The weed control achieved in tanier in Puerto'Rico was not as effective as expected. The discrepancy might be attributed to less humid growing conditions encountered in Puerto Rico. We understand that taro in Hawaii is grown chiefly in irrigated and lowland areas where moisture is more abundant to activate Nitrofen. Perfluidone at either rate was ineffective in controlling morning glory, spurge and sicklepod. Perfluidone provided good control to purple nutsedge, but this species did not constitute a major problem weed in the Isabela area. 
TABLE 1.-Effect of herbicides on weed control, phytotoxicity, and tuber yield in the first tanier experiment (1977-78)

\begin{tabular}{|c|c|c|c|c|c|}
\hline \multirow{2}{*}{ Herbicide } & \multicolumn{2}{|r|}{ Treatments } & \multirow{2}{*}{$\begin{array}{l}\text { Weed control } \\
\text { ratings up } \\
\text { to } 90 \text { days }^{1}\end{array}$} & \multirow{2}{*}{ Phytotoxicity $^{2}$} & \multirow{2}{*}{ Tuber yield $^{3}$} \\
\hline & Preemergence & Postemergence & & & \\
\hline & & & $\%$ & $\%$ & $\mathrm{Kg} / \mathrm{ha}$ \\
\hline Ametryn & $3.36 \mathrm{~kg} / \mathrm{ha}$ & $1.68 \mathrm{~kg} / \mathrm{ha}$ (twice) & 75 & 0 & $2857.8 \mathrm{ab}^{4}$ \\
\hline Ametryn & $6.72 \mathrm{~kg} / \mathrm{ha}$ & $3.36 \mathrm{~kg} / \mathrm{ha}$ (twice) & 79 & 3 & $3738.1 \mathrm{ab}$ \\
\hline Diphenamid & $11.20 \mathrm{~kg} / \mathrm{ha}$ & Glyphosate 2.34 1/ha (once) & 74 & 0 & $3855.6 \mathrm{ab}$ \\
\hline Diphenamid & $22.40 \mathrm{~kg} / \mathrm{ha}$ & Glyphosate 4.681 /ha (once) & 80 & 0 & $5744.7 \mathrm{a}$ \\
\hline Linuron & $3.36 \mathrm{~kg} / \mathrm{ha}$ & $1.68 \mathrm{~kg} / \mathrm{ha}$ (twice) & 80 & 0 & $2247.5 \mathrm{ab}$ \\
\hline Linuron & $6.72 \mathrm{~kg} / \mathrm{ha}$ & $3.36 \mathrm{~kg} / \mathrm{ha}$ (twice) & 91 & 3 & $3100.0 \mathrm{ab}$ \\
\hline Metribuzin & $2.24 \mathrm{~kg} / \mathrm{ha}$ & $1.12 \mathrm{~kg} / \mathrm{ha}$ (twice) & 81 & 18 & $2877.2 \mathrm{ab}$ \\
\hline Metribuzin & $4.48 \mathrm{~kg} / \mathrm{ha}$ & $2.24 \mathrm{~kg} / \mathrm{ha}$ (twice) & 98 & 58 & $77.5 \mathrm{~b}$ \\
\hline Nitrofen & $6.72 \mathrm{~kg} / \mathrm{ha}$ & $3.36 \mathrm{~kg} / \mathrm{ha}$ (twice) & 46 & 0 & $4998.7 \mathrm{a}$ \\
\hline Nitrofen & $13.44 \mathrm{~kg} / \mathrm{ha}$ & $6.72 \mathrm{~kg} / \mathrm{ha}$ (twice) & 78 & 8 & $3003.1 \mathrm{ab}$ \\
\hline Perifluidone & $3.36 \mathrm{~kg} / \mathrm{ha}$ & $1.12 \mathrm{~kg} / \mathrm{ha}$ (twice) & 36 & 0 & $2015.0 \mathrm{ab}$ \\
\hline Perfluidone & $6.72 \mathrm{~kg} / \mathrm{ha}$ & $3.36 \mathrm{~kg} / \mathrm{ha}$ (twice) & 41 & 0 & $339.1 \mathrm{ab}$ \\
\hline Hand-weeded check & - & - & 100 & 0 & $3913.7 \mathrm{ab}$ \\
\hline Unweeded check & - & - & 0 & 0 & $445.6 \mathrm{~b}$ \\
\hline
\end{tabular}

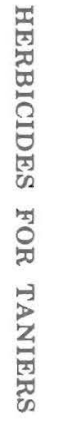

${ }^{1}$ Weed control rating is based on a scale of 0-100: $0=$ no control; $100=$ complete control.

${ }^{2}$ Phytotoxicity is based on a scale of 0-100: $0=$ no phytotoxicity; $100=$ complete kill.

${ }^{3}$ Tuber yield is the average of four replications.

${ }^{4}$ Values followed by one or more letters in common do not differ statistically $(\mathrm{P}=0.05)$. 
Table 1 presents the phytotoxic effect of different herbicide treatments on taniers. Metribuzin was found to be the most phytotoxic among the herbicides tested. Preemergence application of Metribuzin did not cause any visible herbicide injury to taniers. The major tanier injury was caused by postemergence application of Metribuzin. Metribuzin at higher rate almost killed the complete stand of taniers. Neither Ametryn nor Linuron applied preemergently caused any tanier injury. However, veinal chlorosis developed when the rate of Ametryn and Linuron was increased to 6.72 $\mathrm{kg} / \mathrm{ha}$. These symptoms were temporary and later outgrown. Taniers were highly tolerant to Diphenamid. At no time was there any symptom of injury noted even when the rate of Diphenamid was raised to 22.40 $\mathrm{kg} / \mathrm{ha}$. Nitrofen at $6.72 \mathrm{~kg} / \mathrm{ha}$ did not cause any phytotoxic effect on taniers. As the rate of Nitrofen was increased, slight tanier injury was observed. Perfluidone was not phytotoxic at either rate. Tanier injury was not apparent when Glyphosate at 2.34 1/ha and 4.681 /ha was applied as a supplementary treatment to Diphenamid at an advanced stage of tanier growth.

The highest tuber yield was obtained with Diphenamid at $22.40 \mathrm{~kg} / \mathrm{ha}$ as a preemergent and Glyphosate at 4.681 /ha as a postemergent (table 1). Plots treated with Nitrofen at $6.72 \mathrm{~kg} / \mathrm{ha}$ also produced a higher yield than the handweeded check. However, the differences were not statistically significant. Tanier from Ametryn- and Linuron-treated plots yielded somewhat less than handweeded check but again the differences were not statistically significant. Metribuzin at $2.24 \mathrm{~kg} / \mathrm{ha}$ did not significantly reduce the tuber yield as it did at $4.48 \mathrm{~kg} / \mathrm{ha}$. Perfluidone at $3.36 \mathrm{~kg} / \mathrm{ha}$ rate did not reduce significantly tuber yield as Perfluidone at $6.72 \mathrm{~kg} / \mathrm{ha}$ did. Yields of the nonweeded checks were significantly lower than those of handweeded checks.

\section{EXPERIMENT 2}

The predominant weed species present in the experimental plots are listed in their decreasing order of abundance; spurge (Euphorbia heterophylla L.), guinea grass (Panicum maximum Jacq.), morning glory (Ipomoea tiliaceae (Willd.) Choisy), pigweed (Amaranthus dubius Mart.), crabgrass (Digitaria sanguinalis (L.) Scop.), hairy spurge (Chamaesyce hirta (L.) Millsp. small), jungle rice (Echinochloa colonum (L.) Link.), sicklepod (Cassia tora L.), woodsorrel (Oxalis intermedia A. Rich.), Southern sida (Sida acuta Burn T.), lion's ear (Leonotis nepetaefolia (L.) Vahl), balsam apple (Momordica charantia L.), cypress vine morning glory (Ipomoea quamoclit L.), and nutsedge (Cyperus rotundus L.). Table 2 summarizes the weed control ratings. Fluometuron at the rates of 4.48 and $8.96 \mathrm{~kg} / \mathrm{ha}$ provided good preemergence weed control. Application of DCPA and Oryzalin alone gave poor broadleaf weed 
TABLE 2.-Effect of herbicides on weed control, phytotoxicity, and tuber yield in the second tanier experiment (1978-79)

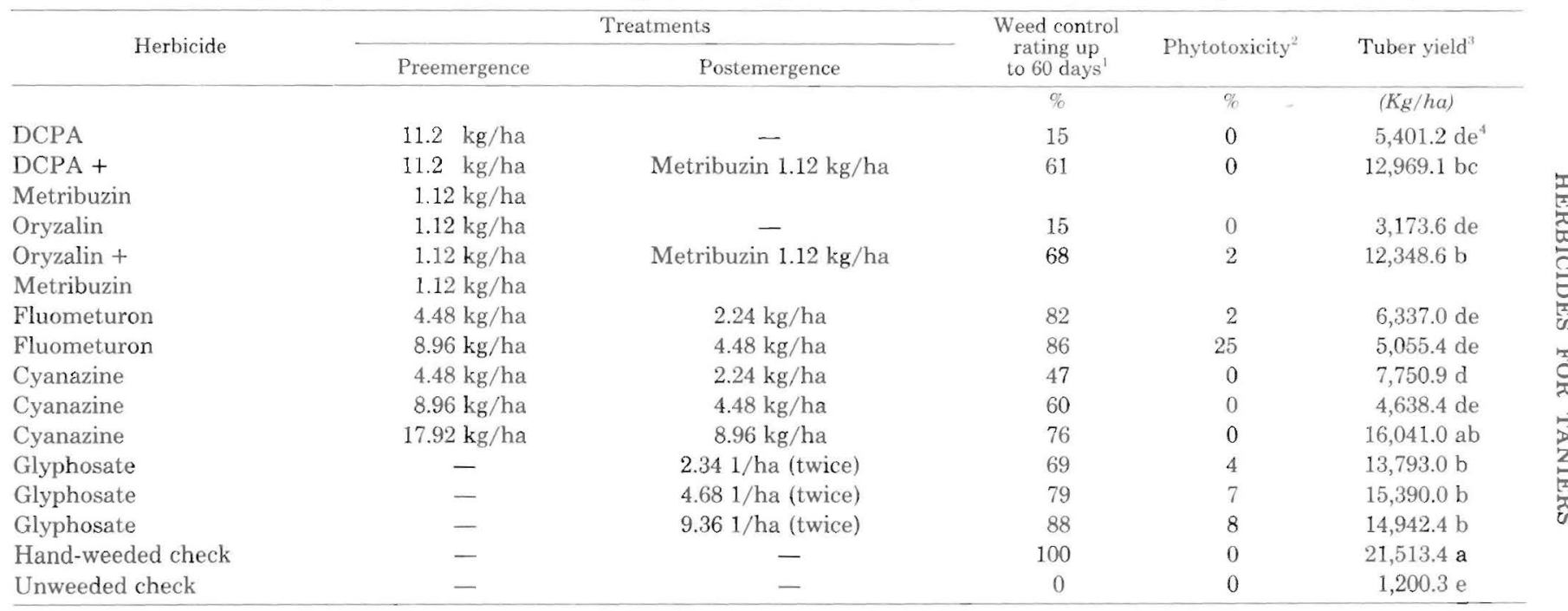

${ }^{1}$ Weed control rating is based on a scale of 0-100: $0=$ no control, $100=$ complete control.

${ }^{2}$ Phytotoxicity is based on a scale of $0-100: 0=$ no phytotoxicity; $100=$ complete kill.

${ }^{3}$ Tuber yield is the average of four replications.

${ }^{4}$ Values followed by one or more letters in common do not differ statistically ( $\left.\mathrm{P}=0.05\right)$. 
control but they were more effective when combined with Metribuzin. Cyanazine at the rates $4.48 \mathrm{~kg} /$ ha gave poor weed control. However, Cyanazine was effective in controlling weeds at an increased rate of 17.92 $\mathrm{kg} / \mathrm{ha}$. Weed control was excellent with postemergence application of Glyphosate.

Table 2 gives the phytotoxic effects of the different herbicides. DCPA and Oryzalin caused no crop injury and proved to be highly selective to taniers. Fluometuron at $4.48 \mathrm{~kg} /$ ha caused only slight injury to taniers. Severe crop injury occurred at an increased rate of Fluometuron application, especially following the postemergence application. Taniers were highly tolerant to Cyanazine and were not injured when treated with a high rate of $17.92 \mathrm{~kg} / \mathrm{ha}$. All three rates of Glyphosate caused crop injury, which was characterized by general yellowing of the whole plant. The injury was apparently caused by the drifting of Glyphosate to leaves during the process of directed spraying. However, 1 month later, the plants had recovered completely, retaining no trace of injury symptoms.

Statistical analyses were made of tuber yield as affected by the different herbicide treatments (table 2). The handweeded checks produced the highest yields. Cyanazine at 4.48 and $8.96 \mathrm{~kg} / \mathrm{ha}$ rate yielded poorly, but Cyanazine at $17.92 \mathrm{~kg} / \mathrm{ha}$ rate produced the second best yield. Cyanazine should be evaluated further at higher rates than those used in this study. Glyphosate at all rates tested produced the third best yield despite injury problem. DCPA and Oryzalin applied alone did not yield well. However, when either was combined with Metribuzin, the yield was greatly improved. Apparently, Metribuzin contributed to the yield increases. Tuber yield was significantly reduced by Fluometuron at both rates of application.

The findings of the two foregoing herbicide experiments indicate that a single preemergence herbicide would not provide the long term weed control required by taniers. Herbicides with good postemergence activity would be needed to give sustained weed control. Glyphosate is the only such postemergence type of herbicide tested in this study. Since Glyphosate injury did not cause drastic yield reduction, there exists the possibility of using a shielded applicator to avoid drift effect. Thus the safety margin of Glyphosate could greatly be improved. With regard to preemergence types of herbicides, Ametryn, Linuron and Metribuzin could be used safely, provided that the rates of these herbicides do not exceed their limits. According to the results of this study, Ametryn and Linuron may be used safely at the rate not exceeding $3.36 \mathrm{~kg} / \mathrm{ha}$, and Metribuzin not exceeding $1.12 \mathrm{~kg} / \mathrm{ha}$. However, none of the above mentioned herbicides has yet received the needed registration required by EPA. 


\section{RESUMEN}

Dos experimentos con herbicidas se establecieron en un suelo Coto arcilloso en la subestación de Isabela para evaluar herbicidas prometedores para controlar los yerbajos en la yautía. La yautía demostró ser muy tolerante al Diphenamid; con el tratamiento combinado de Diphenamid y glifosato se obturo el rendimiento más alto. Las dosis de Ametryn y Linuron lograron también un buen control de los yerbajos. Nitrofen fue muy eficaz solamente a la dosis más alta. Metribuzin y Fluometuron fueron muy eficaces, pero ambos fueron tóxicos al cultivo cuando se usaron cantidades altas. A dosis bajas Cyanazine no surtió efecto, pero fue muy eficaz a dosis más altas. Aunque se corre el riesgo de causar daño a la yautía si no se toman las debidas precauciones, glifosato aplicado solo resulta ser el herbicida por excelencia para el control posemergente de malezas. DCPA, Oryzalin y Perfluidone fueron ineficaces en esta prueba.

En el primer experimento se aplicó Ametryn a razón de 3.36 y 6.72 $\mathrm{kg} / \mathrm{ha}$, Diphenamid a razón de 11.20 y $22.40 \mathrm{~kg} / \mathrm{ha}$, Linuron a razón de 3.36 y $6.72 \mathrm{~kg} / \mathrm{ha}$, Metribuzin a razón de 2.24 y $4.48 \mathrm{~kg} / \mathrm{ha}$, Nitrofen a razón de 6.72 y $13.44 \mathrm{~kg} / \mathrm{ha}$ y Perfluidone a razón de 3.36 y $6.72 \mathrm{~kg} /$ ha. En el segundo se aplicó DCPA a $11.2 \mathrm{~kg} / \mathrm{ha}$ y Oryzalin a $1.12 \mathrm{~kg} / \mathrm{ha}$ solo o en combinación con Metribuzin a $1.12 \mathrm{~kg} / \mathrm{ha}$, Fluometuron a 4.48 y $8.26 \mathrm{~kg} / \mathrm{ha}$, Cyanazine a $4.48,8.96$ y $17.92 \mathrm{~kg} / \mathrm{ha}$, y glifosato a 2.34 , 4.68 y $9.36 \mathrm{I} / \mathrm{ha}$. Todos los herbicidas, con excepción de glifosato, se aplicaron con bombas de mochila a razón de 281 1/ ha. Las aspersiones con glifosato se efectuaron directamente sobre los yerbajos a razón de 468 I/ha.

\section{LITERATURE CITED}

1. Departamento de Agricultura de Puerto Rico, 1977-78. Anuario de Estadísticas Agrícolas de Puerto Rico: Estimados preliminares del ingreso agrícola de Puerto Rico.

2. Kasasian, L. and Seeyave, J., 1968. Weed killers for Caribbean agriculture, Univ. West Indies, Trinidad.

3. Lucas, R., Punu, B., and Cable, W. J., 1973. Aspects of taro production on the shallows calcareous of Niue. Proceedings of 3rd Int. Symp. Trop. Root Crop, Ibadan.

4. Moody, K. and Ezumach, H. C., 1974. Weed control in major tropical root and tuber crops-a review, Pans 20: 292-9.

5. Peña, R. S. de la, 1975. Nitrofen for taro weed control, Circ. Coop. Ext. Serv., Univ. Hawaii No. 488: 4.

6. Plucknett, D. L., Saiki, D. F., and Motooka, P. S., 1967. Weed control in taro (Colocasia esculenta L. Schott). Proc. 1st Asian-Pacific Weed Control Interchange, Honolulu 90-93.

7. — and Peña, R. S. de la, 1971. Taro production in Hawaii, World Crops 23: 244-9. 